\title{
TRUTH, JOURNALS, AND POLITICS: The Case of the MIS Quarterly
}

\author{
Lucas Introna \\ Lancaster University
}

Louise Whittaker

University of the Witwatersrand

\begin{abstract}
In this paper, we want to demonstrate the way in which regimes of truth at the MIS Quarterly (MISQ) have made it possible for certain types of research to be published there, and others not. The importance of this claim lies in the fact that publication in MISQ is often seen as an indication of status. Furthermore, publication in MISQ also plays an important role in decisions about tenure and promotion. However, the aim of the paper is not to rid MISQ of regimes of truth - this is not possible. The paper will argue, with Foucault, that all institutions always already have their politics of truth. The production of truth is always intimately tied to relations of power which itself depends upon truth for its sustenance. The aim of the paper is to show this intimate connection between truth and power. In particular, in the case of MISQ, we want to question the often-implied legitimacy and status that the MISQ has over and against other high quality journals in the field. Foucault argues that power is most effective when it hides itself. This paper is an attempt to make its face more public and open to scrutiny.
\end{abstract}

\section{INTRODUCTION}

There is no doubt that academic journals play an important role in shaping a discipline. Equally, it is generally known that many decisions about the academic careers of university faculty are intimately tied to publication and participation in the socalled leading journals of the field. It would, therefore, be reasonable to argue that these journals should be free from politics; that these journals ought to allow for a level playing field in which networks of power and influence are limited, if not illuminated. Yet this does not seem to be the case as the recent widely published row in economics 
illustrates (Jacobsen 2001). There have been some, like Habermas (1979, 1984, 1987), who have argued that it is only in an apolitical space of rational debate that a discipline can flourish. They argue that all participants must be equal in making and defending truth claims. Although we may want this to be true-and we are not sure we do-we do not believe this will ever be the case. We want to argue, using Foucault (1977), that truth is always a very mundane human affair. As such, human institutions are directly implicated in its production and circulation. With truth we mean statements or claims about the state of affairs that we want others to accept as true. We, like Foucault, are not here interested in absolute truths that are supposed to exist, or not. Every individual may believe what he or she wants - this of no concern to us in this context. However, when someone makes truth claims-about the validity of certain types of research over and above other types, for example - with the expectation that others or we should accept them as such, then truth becomes directly implicated as a human affair. As such, our concern with academic journals as spaces where truth claims are proffered is not directly a concern with the validity (or not) of a particular ontology and epistemology. Rather, our concern is with the way in which any particular ontology and epistemology becomes constituted as more legitimate than others equally valid — especially when it has a material bearing on issues of tenure and promotion. It is important to say from the outset that the claim that a particular regime of truth is operating is not necessarily a claim that there exists an intentional strategy or some sort of a conspiracy or plot to this effect.

We will structure the discussion as follows: first, we want to explain the intimate connection between the production of truth and the mechanisms of power that sustain this production using the Foucauldian notion of regimes of truth; second, we want to outline the way in which regimes of truth functioned and function in the MIS Quarterly (MISQ); and finally, we want to discuss some of the implications of our analysis.

\section{KNOWLEDGE AND POWER: THE CONSTITUTION OF REGIMES OF TRUTH}

In opposition to the modem view that knowledge gets produced in a zone where power is suspended, Foucault argues that any attempt to separate power and knowledge is futile since the production of knowledge is political all the way down. To separate knowledge and power would be to claim that we could separate statements of fact from the values and mechanisms that constitute them as such. Latour $(1987,1993)$ has convincingly argued that what we find in practice is that "facts do not speak for themselves." Facts are produced as facts because we value them as such. It is institutional mechanisms and practices that give facts a voice in the first instance. They become constituted as facts through processes, procedures, and discursive practices that produce them and are likewise produced by them. For example, in the modem scientific regime of truth we value scientific method and, therefore, wejudge its products to be facts. We do not value intuition and, therefore, we judge it products to be speculation. One could say that facts are merely legitimized value choices accorded that status through the prevailing institutional mechanisms. Thus, for every recognized fact (or set of facts) one could always, in principle, find the institutional mechanism that accords it that status and 
which is itself dependent on that status. For example, the valuing of profit becomes sedimented as facts in the income statement and balance sheet of the company, which are themselves necessary to sustain that value. Through the rituals of accounting practices and stock exchanges, the income statement and balance sheet become constituted as truth at the expense of equally valid alternative values, such as environmental or employee concerns. Nietzsche (1967) writes in Will to Power: "But what is truth? Perhaps a kind of belief that has become a condition for life" (p. 248)—or as Foucault later articulates it more clearly, truth simply means beliefs that have become a condition for that institution to sustain itself as that which it believes it is.

Every attempt to secure knowledge in a zone outside of power will itself become a resource for power. For we should, as Foucault argues, "admit rather...that there is no power relation without the correlative constitution of a field of knowledge, nor any knowledge that does not presuppose and constitute at the same time power relations" (1977, p. 486). The linking of power and knowledge through discourse gives rise to what he calls regimes of truth. A regime of truth is the institutional infrastructure for the production and circulation of truth claims. Truth is produced in and through institutionalized discursive practices - in our discussion below, for example, we will look at editorial statements and other claims made in the MISQ as such discourse. Discourse here is understood as a particular way of talking, of making statements or claims, about the state of affairs. Truth, as pointed out above, is understood as claims about the world that are proffered as valid claims within a particular regime of truth —claims those that make them expect us to accept as valid. Foucault (1977) argued that each institution or society has its "regime of truth, its 'general politics' of truth." A particular regime of truth is constituted through a set of mechanisms and discursive practices which legitimizes claims and is itself dependent on the legitimacy of those claims. In Power/ Knowledge Foucault (1977, p. 131) mentions the following mechanisms and practices that constitute a particular regime of truth:

- The types of discourse that it accepts and makes function as true. Clearly, not all discourse in institutions functions as truth claims. For example when we present this paper at an academic conference we are proffering truth claims in a way we are not when chatting to a colleague in the corridor about the paper.

- The mechanisms and instances that enable one to distinguish true andfalse statements. Once we occasion certain discursive moments as instances of truth making, we must set in place the mechanisms for identifying true statements from false statements. How will these be verified?

- The means by which each is sanctioned. Truth is not produced if it is not sanctioned. Presenting the paper to our peers at an academic conference is one of the practices to sanction the truth claims we are proffering.

- The techniques and procedures accorded value in the acquisition of truth. In distinguishing true from false statements, and in sanctioning these, careful attention is given to the techniques and procedures used in the construction of these truth claims.

- The states of those who are charged with saying what counts as true. In institutions, the charge of acknowledging truth claims is carefully distributed and controlled. The auditor is charged to make claims about the financial status of the 
organization in a way that the marketing manager is not. However, to make these statements the auditor must be at least a certified accountant. Likewise, we normally require professors as examiners of Ph.D. dissertations.

In regimes of truth "[truth] is linked in a circular relation with systems of power which it induces and which extend it" (Foucault 1977, p. 133) Power, through micropractices and mechanisms of meaning, membership, and discipline (Clegg 1989), structures and restructures discourse, a way of talking about the world, in a discontinuous and diffused manner. Owing to the non-egalitarian and diffused nature of the relationship, such discourse gives rise to a particular regime of truth. The regime of truth in turn produces discursive resources in support of the very power relations that constitutes it. Power and truth are co-constitutive.

If claims of truth are always already within an existing sets of power relations, as Foucault claims, then we can only exchange one regime of truth for another. In knowledge production, which is a fundamentally social enterprise, we can not escape power (as proposed by Habermas [1984, 1987] in his ideal speech situation). Every ideal speech situation will always already assume a regime of truth for its very existence. Of course, we could say that in some cases power relations can become systemically asymmetrical as in a dictatorial state or monopolistic market, although Foucault will deny this. He would argue that even the king is only king because of a whole network of alliances that must constantly be serviced and secured. Even the big positive research programs in the natural sciences-that supposedly produce objective, value free truth-must make deals and produce the appropriate truth to secure funding, publications, and so forth.

Let us consider the notion of a regime of truth more closely by developing contrasting examples of the regimes of truth in different institutions. In Table 1, we present a comparison of the publication of a paper in a peer-reviewed journal (in scientific institutions) with the publishing of the annual report of a public company (in the capitalist enterprise), with the delivery of a sermon in a church service (in the Christian church). The table aims to show that each of these institutions have an identifiable set of institutional mechanisms and practices to produce what will be considered truth in that particular institution. Although these mechanisms and practices differ widely from institution to institution, they serve essentially the same purpose: namely, to ensure the production of truth in a manner that would sustain the institution as that which it claims to be.

In the table, we can observe the interplay between power and knowledge (in and through truth claims). Through a set ofmechanisms, techniques, and sanctions, the truth is produced and confirmed as such. The mechanisms and practices are constituted through relations of power in such a manner that the truth produced would maintain and sustain these very relations of power. It is this relation between power and truth that stabilizes the institution (one can think of Kuhn's [1970] studies here; however, from this perspective we should say that his paradigm shifts are more shifts in power than shifts in epistemology/ontology). Any regime of truth, irrespective of its power relations, is always under threat. As Kuhn indicated, such shifts in power might be evolutionary or revolutionary, but regimes of truth are never fixed. Nevertheless, they do not necessary represent a conspiracy or a plot of some sort, as mentioned above. Their 
Table 1. Regimes of Truth in Different Institutions

\begin{tabular}{|c|c|c|c|}
\hline Regime of Truth & Institutions of Science & Capitalist Enterprise & Christian Church \\
\hline $\begin{array}{l}\text { Types of } \\
\text { discourse which } \\
\text { it accepts and } \\
\text { makes function as } \\
\text { true }\end{array}$ & $\begin{array}{l}\text { Publishing a paper in } \\
\text { a peer reviewed } \\
\text { journal, Defending a } \\
\text { Ph.D.; presenting a } \\
\text { conference paper, etc. }\end{array}$ & $\begin{array}{l}\text { Publishing the } \\
\text { annual company } \\
\text { report, AGM, } \\
\text { annualemployment } \\
\text { review, etc. }\end{array}$ & $\begin{array}{l}\text { Delivering the } \\
\text { sermon, adminis- } \\
\text { tering the sacra- } \\
\text { ments, counseling a } \\
\text { member of the } \\
\text { church, etc. }\end{array}$ \\
\hline $\begin{array}{l}\text { Mechanisms and } \\
\text { instances for } \\
\text { distinguishing } \\
\text { true and false } \\
\text { statements }\end{array}$ & $\begin{array}{l}\text { Scientific argument } \\
\text { and proof, } \\
\text { (dis)agreements in } \\
\text { viva, using canonical } \\
\text { texts/authority, etc. }\end{array}$ & $\begin{array}{l}\text { Review by the } \\
\text { auditors, economic } \\
\text { argument (effi- } \\
\text { ciency, profita- } \\
\text { bility), appealing to } \\
\text { canonical texts } \\
\text { (Porter, etc.) or } \\
\text { consultants, etc. }\end{array}$ & $\begin{array}{l}\text { Review of sermon by } \\
\text { the church elders, } \\
\text { use of canonical text } \\
\text { for authority, } \\
\text { appealing to a higher } \\
\text { church authority (for } \\
\text { example, the bishop), } \\
\text { etc. }\end{array}$ \\
\hline $\begin{array}{l}\text { The means by } \\
\text { which each is } \\
\text { sanctioned }\end{array}$ & $\begin{array}{l}\text { Review by peers, } \\
\text { publication in journal, } \\
\text { citation in subsequent } \\
\text { papers, citation, and } \\
\text { journal indices. }\end{array}$ & $\begin{array}{l}\text { Report presented to } \\
\text { the board of } \\
\text { directors, delivered } \\
\text { at the AGM as the } \\
\text { official financial } \\
\text { position of the } \\
\text { company, reaction } \\
\text { of stock exchange, } \\
\text { etc. }\end{array}$ & $\begin{array}{l}\text { Sermon delivered as } \\
\text { part of liturgy, starts } \\
\text { with (or follows) the } \\
\text { reading from bible, } \\
\text { sermon starts or ends } \\
\text { with "so says the } \\
\text { Lord." }\end{array}$ \\
\hline $\begin{array}{l}\text { Techniques and } \\
\text { procedures } \\
\text { accorded value in } \\
\text { the acquisition of } \\
\text { truth } \\
\end{array}$ & $\begin{array}{l}\text { Scientific } \\
\text { method/research } \\
\text { method }\end{array}$ & $\begin{array}{l}\text { General accepted } \\
\text { accounting practices } \\
\text { (GAAP), audit } \\
\text { process, strategic } \\
\text { planning, etc. }\end{array}$ & $\begin{array}{l}\text { Biblical exegesis, } \\
\text { interpretations of } \\
\text { church edicts, etc. }\end{array}$ \\
\hline $\begin{array}{l}\text { Thestates of } \\
\text { those who are } \\
\text { charged with } \\
\text { saying what } \\
\text { counts as true }\end{array}$ & $\begin{array}{l}\text { Reviewers must be } \\
\text { recognized experts in } \\
\text { their field, editors } \\
\text { must be seen to be } \\
\text { objective, acting on } \\
\text { behalf of academic } \\
\text { community. }\end{array}$ & $\begin{array}{l}\text { Auditor must be a } \\
\text { chartered auditor, } \\
\text { managing director } \\
\text { acts ex officio on } \\
\text { behalf of the } \\
\text { shareholders, etc. }\end{array}$ & $\begin{array}{l}\text { Must be a licensed } \\
\text { minister or religion, } \\
\text { and an appointed } \\
\text { leader in a } \\
\text { congregation }\end{array}$ \\
\hline
\end{tabular}

origins and sustenance are often due to contingent events that are seized upon as resources for the play of power. The "logic is clear, the aims decipherable, and yet it is often the case that no one is there to have invented them" (Foucault 1977, p. 486). The local tactics may link together and combine into overall strategies that create the illusion of grand design but are in fact outcomes of very local contingent actions.

Every claim to truth whatsoever always implies a regime of truth for its force or validity. Some regimes of truth may be subtle and mobile and others more explicit and fixed. For example, in a family, husband and wife have the ability to make truth claims in a way that children cannot. This is because of the relations of power constituted by 
their access to resources of power, such as the sanction by society of their role as parents and guardians. Yet, this regime of truth is continually open for dispute and maneuvering in a way that a court of law is not. Thus, no claim to truth can be made outside of a regime of truth —not even in the intimacy of a family. The production of truth is never outside of power.

It is also the case, however, that in some instances, there are blocks in which power and truth, as claimed through resources of communication and objective capacities, constitute regulated and concerted systems, or disciplines, in an enlarged sense of the word. In this regard, Foucault (1994) refers to monastic, penitential, medical, and technical disciplines as examples. Certainly the general understanding of information systems as an academic discipline would fall within this definition. For even given its, in some quarters notorious, lack of consensus as to what rightfully constitutes the discipline, there are nonetheless powerful regulatory processes that ensure aptitudes and particular types of behavior, across and within institutions in which the discipline is taught. Indeed, it has been a specific objective of academics within the discipline, since the mid-1960s at least, to "be a profession" (Dickson 1982, p. v), as much as medicine or engineering are professions.

Within a discipline, the specificities of power relations are made clearer, perhaps, than in less regulated regimes of truth. And yet they cannot by any means be said to be fixed or unidirectional, since it is easy to see that "all forms of dependence offer some resources whereby those who are subordinate can influence the activities of the superiors" (Giddens 1984, p.16). Foucault, in fact goes further than this: "Power is exercised only over free subjects, and only insofar as they are "free." Power relations exist where individuals have a field of possibilities, however sparse these may be, and even though the power relations are inscribed in the more or less permanent structures underpinning that field. In any relationship of power, "a whole field of responses, reactions, results and possible inventions may open up" (Foucault 1994, p. 340). This implies, then, that intertwined as they are with power, the mechanisms used to produce truth in any discipline are inherently contingent. Through intentional and unintentional moves, these regimes of truth are continually shifting, opening spaces for certain types of research to become legitimate and others not.

Within information systems as a discipline, the MIS Quarterly, as a leading journal, is one of those mechanisms used to validate both the truth claims made by the discipline, and the discipline itself. Further, in so far as the MISQ is a regulated and concerted "conduct of conduct" or leader of behavior in the production of truth, it can itself be said to be a discipline, in Foucault's enlarged sense of the word. In the sections that follow, we want to analyze some of the mechanisms that constitute the regimes of truth of the MISQ, with a view to showing, first, that these do in fact operate and, second, just how contingent they are. Our analysis is by no means comprehensive or complete. It merely suggests some outlines of such an analysis.

\section{REGIMES OF TRUTH AT THE MISQ}

The MISQ was established in 1977 with Gary W. Dickson as Editor-in-Chief. Dickson's tenure lasted six years. Thereafter, editors were appointed for three-year 
terms (see Appendix A for the list of past and present editors). For the analysis, we focus on the period between 1981 and 2003 since we have access to journals only from 1981 . Dickson's “Apology of a Retiring Founding Editor (6:4) ${ }^{1}$, does, however, give us some insight into the workings of the journal in the first five years.

Obviously, there are many elements that constitute the regime of truth at the MISQ, or any academic journal for that matter. We as academics are quite familiar with these. They are the editors (past and present), associate editors, the mission or scope of the journal, editorial statements, the review process, keyword classification systems, and so forth. In the regime of truth no one person pulls all the strings. One may be tempted to think the editors do have many of the strings in their hands. Nevertheless, as Foucault argued, the king is only king as long as he can maintain the alliances that legitimize him as king and are themselves dependent on the legitimacy of the king as king. Editors have to continually defend their own legitimacy in the face of previous editors, associate editors, authors, and readers - to name but a few. Thus, to really get a picture of the regimes of truth at MISQ, we would need to trace a multiplicity of relations, statements, codes, processes, and mechanisms operating there. When we do this, we will see that these are multiple, mundane, and contingent. Nevertheless, they do weave together a fairly coherent network of resources for the execution of power that allows certain papers to be judged as true, valid, and legitimate and others not.

It is beyond the scope of this paper to do such a detailed analysis. We are further conscious that, even were it not, "the analysis of power relations...cannot be reduced to the study of a series of institutions" (Foucault 1994, p. 345). Power relations are rooted in the whole network of the discipline. What Foucault does suggest is that a "certain number of points be established." We will attempt to trace some of the power relations constituting this regime of truth by addressing some of these points in the MISQ. In particular we will focus on the types of objectives pursued, in the form of the scope of the journal; and the instrumental modes of action, or rules, in the form of the definition of legitimate research method, as these have shifted over the past 20-odd years.

\subsection{The Shifting Scope of the MISQ: From Managerial Issues and Practice to Technology and Organizational Research Problems}

When the MISQ was established in 1977, its scope was described as "Our major goals are to be managerially oriented and to offer something of benefit to the practitioner. At the same time, we intend to provide a vehicle for researchers working in the information systems field to communicate with each other and with practitioners." This objective is not surprising as the MISQ was at the time a cosponsored project of The Society for Management Information Systems-later to become the Society for

${ }^{1}$ We will only refer to the volume and issue number (volume:issue) in referencing the editorial comments of the editors. The editorial comments are usually only three to five pages so the text being referenced should be easy to locate. 
Information Management — and the University of Minnesota's Management Information Systems Research Center (MISRC). In fact, as Dickson noted upon his retirement, "we wanted a journal in which MIS academics could publish while our primary source of funding was a society of information systems practitioners" (6:4). This dual focus of managerial orientation as well as research forum arose from the task of specifying a product that could satisfy both groups. Initially, this dual focus was maintained by establishing a two-section journal, and by appointing both practitioners and academics as consulting and associate editors. As it evolved, it became articulated as the tension between rigor and relevance.

William King, on his appointment, suggested that his objective was to improve on the "quality and credibility of the journal" (7:1), with the expressed intention of improving its scientific credibility and its use in tenure and promotion decisions (7:2). At the same time, he was anxious to "recognize the importance of both research and applications." However, it is certainly the case that King succeeded in raising the profile of a struggling journal, ${ }^{2}$ not least by nurturing credibility for MISQ as an academic journal, personally lobbying universities to recognize it in promotion criteria (9:4), and getting it listed on databases like ISI (8:4). He also dropped the practitioner-only consulting board for "turnaround-time on review" reasons (9:1), and the number of academics on the associate editors board increased. The journal became steadily more academic in its focus, in that the in-coming third editor, Warren McFarlan, suggested that "sound research-based articles" were now at the "very core of the journal's editorial philosophy." (This despite the fact that neither the editorial policy board, nor the official editorial policy per se, had changed at all over this time.) And while McFarlan seems to have confined himself in editorial statements to reflecting on practically based tools, approaches, and insights, it was in his tenure that Izak Benbasat was appointed (without comment) as Senior Associate Editor of Theory and Research (11:1). Under Benbasat's "primary editorial responsibility for all papers classified as Theory and Research," quantitative, positive research started to dominate the journal. ${ }^{3}$ The split in the editorial board between Research and Theory and Application was dropped in the final year of McFarlan's editorship and a single all-academic board established. Nonetheless, much as Dickson had done, McFarlan closed his editorship with a comment on the tension between theory and practice, and a plea to practitioners and academics to "establish a dialogue" (12:1).

James Emery, too, highlighted the need to "provide a forum for materials addressing the information systems field in both theory and practice... [hopefully] thereby, to unite the efforts of those teaching and doing research in this area with those applying information systems to organizational problems" (13:3). This, however, was to be done with an emphasis of adding to the body of knowledge, as the screening of application

${ }^{2} \mathrm{~A}$ "hand-to-mouth" editorial existence forced the late production of the first two issues of volume 7 (8:4).

${ }^{3}$ A detailed classification of all papers published in the period under discussion is beyond the scope of this paper, for reasons of length, but a review of all empirical research papers published in this period shows them to be positivist, and overwhelming quantitative. 
papers became more rigorous through the application of the criteria of generalizability, delimitations of scope, and reference to the existing literature (13:4). Where application papers were published that did not "satisfy the standard criteria for research"- and these were now presumed to be understood - their inclusion was explicitly justified (14:4). Unsurprisingly, having become a recognized academic journal, relevance to the practitioner community now emerged as specifically problematic. Emery closed his tenure by suggesting that "practitioners must also bear part of the burden of translating theory into practice" (14:4).

In the tenure of Blake Ives, this tension became even more apparent. He argued,

The business school is a professional school with obvious linkages to the business professions. Drawing a parallel to the business school, a colleague recently asked what we would think of medical schools whose research did not address the treatment of disease? Too often business school research addresses problems of little relevance or, equally damaging, fails to be tested in the world of practice. $(16: 1)$

The managerial concern of MISQ was also highlighted by his incoming Senior Editor of Theory and Research, Gerardine DeSanctis: "One of the most distinguishing characteristics of the MIS Quarterly as compared to other journals devoted to information systems is its emphasis on management." Nevertheless she explicitly broadened the definition of management to "include management of public and private organizations, government and labor organizations, and professional and social societies." She equally made it clear that "[a] managerial emphasis does not mean that every paper will have direct implications for practicing management, nor does it mean that every paper in its entirety will appeal to all readers.. .we do not apologize for publishing papers that fail to reap so-called 'real world relevance.' The potential for relevance is what matters" (17:1, emphasis added).

In 1995, when Bob Zmud took over as Senior Editor, the MISQ was unbundled as an automatic subscription benefit with the Society for Information Management (SIM) membership. The institutional arrangement that had demanded both Theory and Application in the first instance was dissolved, and a major practitioner audience was lost. With this change in mind, Zmud suggested that a move away from practitioners concerns had now become possible although he did not support such a move: "this changed relationship also raises the possibility that the Quarterly, given a potential of fewer practitioner readers, could redirect its direction toward the academic community and away from the practitioner community. I wish to state as strongly as possible that this is not my intention"(19:1). This stated commitment became less apparent as he sought to improve the theoretical foundations of the papers in MISQ. As for the scope of papers appropriate for the journal, some minor but important shifts are also noticeable. He saw the MISQ editorial objective to be "the development and communication of knowledge concerning both the management of information technology and the use of information technology for managerial and organizational purposes" (19:2). He clarified "the operative terms... are: management, information, and information techno$\operatorname{logy} . . .$. Notice that who exactly is involved in the act of managing is left open." This emphasis on managing rather than managers is important as it opened up the horizon 
for research that is less managerialist. Toward the end of his first year as Senior Editor, Zmud made a strong appeal for theory as the foundation of all MISQ papers: "Adequate theory development is a fundamental requirement for all manuscripts submitted to the Quarterly.... All manuscripts submitted to the Quarterly — this includes both 'Theory and Research' and 'Applications' articles-must have a theory section" (19:3). He also indicated what he did not want to see in MISQ: "pragmatic descriptions of information systems applications, methodologies, or practices; formal descriptions of information systems applications, methodologies, or practices; replications of prior studies; and criticisms of prior studies." These topics, especially the first two, were very much "the stuff" for MISQ in the 1970s and 1980s. As the theory focus of MISQ grew, Zmud introduced an interesting new distinction between weak relevance and strong relevance. He explained: "An article can be said to demonstrate weak relevance when the research questions being examined touch on organizational phenomena that are clearly of interest to practice, and I expect all articles submitted to MIS Quarterly to minimally demonstrate weak relevance" (20:3, emphasis added). He further clarified that strong relevance is accomplished when "(1) using the concerns of practice (rather than scientific literature) as the primary motivation behind the research effort being described in an article, and (2) clearly discussing the meaningfulness of the article's scientific contributions to the executive audience" (20:3). In his last year as Editor-in-Chief, Zmud made an rather unusual appeal for pure theory papers: "I wish to encourage the MIS Quarterly readership to consider submitting manuscripts whose primary contribution lies with the theory being developed and articulated" (22:2). Zmud's commitment to move MISQ toward an academically and intellectually respectable position was most clearly demonstrated when he suggested in his final Editor's Comments that the Research/ Application divisions, long at the heart of MISQ's dual focus, be abandoned. As Zmud left office, MISQ had become a journal with a strong emphasis of theory in which most papers had only weak relevance. This is a very significant distance away from the happy marriage of its early years.

In his inaugural editorial comments, Allen Lee confirmed this direction: "I am more than happy to accept the responsibility... to secure MIS Quarterly's place among the best research journals in the academic field of MIS." (23:1, emphasis added). Maybe it is a Freudian slip but there is no mention of the other half of the relationship here. He also announced the consolidation of the Theory and Research department and the Application department as suggested by Zmud. The new department was to be called Research and publish "Articles that are 'pure theory,' articles that empirically test or illustrate theory and articles that apply existing theory." In his second editorial comments (23:2), Lee argued for a further broadening of the editorial scope to include social and political dimensions: "authors can make their papers more likely to be compelling and significant if they additionally attend to the social andpolitical dimensions of their craft," and not only on the "traditional "objective' (cognitive and intellectual) dimensions of research" (23:2). The push toward theory-driven work that is academically and intellectually rigorous and legitimate at the expense of that which practitioners may want and find relevant surfaced again toward the end of Lee's second year. In his editorial comments, the actual commitment of MISQ was made abundantly clear:

Must all instances of information systems research [that which MISQ publishes] be directly consumable by and have immediate relevance to 
managers, executives, consultants, and other practitioners? Must all information systems research be targeted at practitioners? Absolutely not!" (24:3)

He explained - quite correctly in our view - that the relations of power in academic institutions that govern decisions about tenure and promotions (its regime of truth) are not commensurable with those expected in business practice. In our view, he identified the most important problem that plagued MISQ from the start: The regimes of truth of academia are not commensurable with the regimes of truth of business practice. He therefore proposed that a new and differentjournal be established for the now-alienated and illegitimate half brother-the MISQ Executive: "This line of reasoning has motivated me to work with Jeanne Ross and Michael Vitale in pursuing the possibility of starting a new MIS Quarterly publication (other MISQ publications are MISQDiscovery and MISQ Review) whose mission would be the publication of research that would appeal immediately to managers, executives, consultants, and other practitioners. The organizational change would involve the instituting of new editorial and reviewing norms, emphasizing practicality and relevance.... Plans are still at a preliminary stage for the new publication, tentatively named MISQ Executive" (24:3, emphasis added). In fact, as it was launched in 2001, MISQ Executive seemed to look very much like the original MISQ: "targeting two audiences: information systems practitioners and information systems academics" (26:2). With this move, MISQ finally shed its dual focus to become an exclusively academic journal. ${ }^{4}$ This was not seen as a problem, as there will "always be a place for the theory-oriented, basic research of the kind that now predominates in MIS Quarterly" (24:3).

Taking up his tenure, the current editor, Ron Weber, similarly commented that, "Clearly we need to publish the best research undertaken within the information systems discipline," in defense of the MISQ's position "among the very topjournals" in all three of the fields of information systems, computer science and management (26:1). He further extended the research scope of the journal to include the managerial and organizational implications of "the full gamut of topics that command the attention of researchers in the information systems field" (26:1, emphasis added). A significant institutional change occurred under the editorship of Weber, with the establishment of an alliance between the Association for Information Systems (of which Weber is a past President) and the MISQ. This alliance was driven by economic imperatives. Once again, the costs of maintaining a journal had become prohibitive for the independent journal, such that MISQ faced an uncertain future. In this case, however, the alliance created a tension not between theory and practice, but rather between twojournals that "seek to publish high-quality research papers," namely MISQ and the Journal of the AIS (26:3). The effect that this may or may not have on the scope of each journal will be interesting to observe. Weber has, further to this development, editorialized on the need for IS researchers to identify and research the "deep, substantive problems" in the field (27:1). He argues that MISQ has prioritized rigor over relevance, but now relevance has

${ }^{4} \mathrm{~A}$ small, but telling, detail in the academic evolution of the journal is the switch from only the month and year of publication appearing in the footnote of each page, to a volume, issue/month and year footnote, more typical of purely academicjournals. 
taken on a different meaning. Weber is apparently precisely not concerned with relevance to practitioners (as the abolition of executive overviews in the same issue indicates), but with "the most important problems," those that have longevity. In this editorial, Weber appears to address the nature of information systems as a discipline, MISQ being the leading research outlet in that discipline, while acknowledging in this, and his following editorial (27:2) that this has been an ongoing debate since at least the mid-1980s. He further determines the purpose of the MISQ as being to defend, or perhaps establish, depending on one's position, the core of our discipline, and not to "stretch the boundaries of our discipline to an extreme" (27:2). Thus the current editor has quite clearly articulated MISQ's role as defender and protector of the research scope of IS as a discipline.

In this narrative, we have traced the shifting editorial scope of the MISQ. We aimed to demonstrate that this shift happened through many individual statements in the editorial comments, and perhaps also gradual changes in the structure and constitution of the editorial boards, as well as the MISQ's institutional arrangements. We would claim that this shift was not a plot or a strategy in the minds of the editors as such. Nevertheless, papers that were very legitimate bearers of truth in the 1970s and 1980s would not get a second look by the editors today. Likewise, most executives reading MISQ today would probably now agree with the quote from Blake Ives in (16:1) in his editorial comments of 1992: "They say nothing in these articles and they say it in a pretentious way." In the following section, we will consider how research methodology as the legitimate techniques and procedures accorded value in the acquisition of truth also shifted.

\subsection{The Battle of Method at MISQ: From Positivism to Pluralism (of Some Sort)}

In the first 10 years of the MISQ, method was not seen as an issue-mostly because rigor in research was not the only criteria for the acceptance of papers. Many papers that were seen as highly relevant were published irrespective of their theory and their research methods. We can thus see that the points of power relations are not only contingent, but also intertwined, as the scope issue directly affected the method issue. It was furthermore evident to most in the field that the positive methods of the natural sciences were the way to do scientific research. Thus, the issue ofmethod, where it arose at all, was self-evident and quickly subsided again. It was with appointment ofBenbasat as the first Senior Associate Editor of Theory and Research in 1987, that method became articulated as an issue, as the first papers actually reflecting on positivist research methods were published (Benbasat, Goldstein, and Mead 1987; Cuban 1987; Culnan and Swanson 1986). As noted above, the editor at that time, McFarlan, did not discuss questions of method at all. It was first in the tenure of James Emery that the positive methodological criteria for a paper in the Theory and Research category were clarified:

It should be based on a set of well-defined hypotheses, unbiased and reproducible procedures for collecting evidence that supports or refutes the hypotheses, and sound analytical procedures for drawing appropriate 
conclusions from the evidence. The research often involves the collection of considerable quantitative data through such means as laboratory experiments or survey instruments. The data are then subjected to statistical analysis to draw the appropriate inferences from the research (13:3).

Emery did, however, hint that there might be an alternative: "High quality research need not be limited to work generating large quantities of data that can be statistically validated, however: a well constructed case study can also meet the tests of rigorous research." The emphasis on positivism is not surprising as it is clearly evident in the work of Benbasat and Ginsberg as Senior Associate Editors of Theory and Research. In the tenure of Blake Ives, DeSanctis-also as Senior Associate Editor of Theory and Research - made a plea for strong theoretical and empirical work that would provide "fresh theoretical ideas about causal relationships in order to facilitate understanding and prediction of events in the world" (DeSanctis, 17:1). This is in opposition to the dominance of managerial frameworks: "Frameworks are useful systems for identifying and organizing variables for scientists to study; but they do not lend good insight into cause/effect relationships, nor do they articulate the properties and behaviors underlying phenomena" (DeSanctis, 17:1). She also started to open the door for other research approaches: "On the empirical side, we welcome research based on positivist, interpretive, or integrated approaches. Traditionally, MIS Quarterly has emphasized positivist research methods. Though we remain strong in our commitment to hypotheses testing and quantitative data analysis, we would like to stress our interest in research that applies interpretive techniques, such as case studies, textual analysis, ethnography, and participant/ observation" (DeSanctis, 17:1). In spite of this declaration of openness and a restatement of this commitment of "openness with regard to the research methods" by Zmud (19:3), they seemed not to receive other approaches as submissions. Zmud explained: "We truly believe the Quarterly is not biased against manuscripts that adopt other than positivistic perspectives and methods. If it seems that positivistic articles tend to dominate the Quarterly, a sound explanation does exist—-the majority of submitted manuscripts adopt such a perspective. We strongly encourage a variety of research approaches" (19:3). These are very interesting statements. They show us that the editors do indeed not have all the strings of the regime of truth in their hands. They can only work with the resources available. If they do not get non-positivist submissions, they cannot enact a shift in the regime of truth, even if they want to.

In an attempt to establish a new, more pluralistic, regime of truth it was decided to create a special issue on "Intensive Research in Information Systems: Using Qualitative, Interpretive, and Case Methods to Study Information Technology"- under the editorship of Lynn Markus and Allen Lee. The first articles of this special issue appeared as volume 23, issue one, the first issue of Lee's tenure. Other attempts were also made to increase the legitimacy of non-positivistic research such as the publication of Michael Myers' site on "Qualitative Research in Information Systems" in MISQ Discovery (21:2). One can only speculate about why it required such explicit effort for the editors to change the regime of truth with regard to method. We would venture to say that we must not forget that the MISQ itselfoperated in a regime oftruth of management schools (where tenure and promotion decisions were made). Maybe this regime of truth still valued positivist research and, therefore, the authors continued to produce positivist 
research in spite of the attempts of the editors to preach pluralism. The regime of truth of methodological pluralism is sealed in the editorial statements of Allen Lee at the start of his second year. He concluded, after reviewing some examples of published work in MISQ, that the "MIS Quarterly welcomes: the research would (1) be positivist, quantitative, and mathematical, (2) involve a rationalistic/economic decision-making framework, and (3) conduct hypothesis testing," also that the MISQ welcomes "(1) qualitative, interpretive, and case research, (2) a historical framework, and (3) theory building" (24:1). More pluralistic than this one cannot get—-besides allowing speculative philosophical essays (like this one).

Recently there has been continued evidence of such pluralism - there were, in our estimation, three interpretive papers about research in 2001 and 2002 (Baskerville and Myers 2002; Orlikowski and Barley 2001; Schultze and Leidner 2002)—while the special issue articles edited by Bob Zmud on "Redefining the Organizational Roles of Information Technology in the Information Age" appearing in September 2002 and June 2003 contained a number of papers that address more interpretive issues. Interestingly, Weber has explicitly dismissed methodology as a concern, because he is concerned very much with the problem of the problem (that is, scope). He suggests that "we need to change some deeply ingrained mindsets,' specifically, the way in which "our identity as researchers is a function of the extent to which we can flex our muscles using a particular research approach or method." He identifies this mindset as "a vestige of the old 'methodology wars' that occurred long ago in our discipline," and concludes "it is time to forget and move on" (27:1). Clearly the methodology wars have, in the view of the editor, been won, or least there is some kind of truce declared.

We hope to have shown here how the regime of truth with regard to method has change over the tenure of the last four editors of MISQ. It ought to be clear that work, legitimate early on in the 1970s and 1980s both with respect to scope and method, will no longer be legitimate, or not. Nevertheless, there is still a strong emphasis on empirical work. Thus, critical and speculative work will still find it hard to get an audience in MISQ. This analysis of the regimes of truth of the MISQ is still very superficial. We have not analyzed the editorial board, the relationships between the editorial board members, the way in which Senior Editors are chosen, the actual reviewing practices, and so forth. All of these may, to a lesser or greater degree, have shifted the regime of truth of the MISQ in a particular direction rather than another. We want to conclude the paper by looking at some of the implications of the analysis.

\section{TOWARD A BETTER POLITICS OF KNOWLEDGE}

We first want to comment on a philosophical issue then say more about academic publishing. If we admit that truth is not some essential ontological claim-as the moderns assumed — but rather a claim for legitimacy of epistemological categories, does this mean we are now adrift in a sea of relativism in which anything goes? We would claim not. For as much as we want our truth claims to be recognized as such, we will have to appeal to the regime of truth that operates. We can claim all sorts of things about MISQ, but in as much as we want to publish our work there, we will have to address ourselves to the regime of truth that operates there, likewise for all other journals and 
discourses of science. Every form of relativism (or fundamentalism) will eventually be mediated by the regimes of truth that operate in the institutions where it seeks legitimacy. We do not have guarantees nor an ultimate foundation or meta-narrative that we can appeal to for the legitimacy of our truth claims outside ofpower. Nevertheless, this does not mean truth is an arbitrary process. Likewise, from an ethical point of view, every person will have to mediate and reconsider their values subject to those regimes of truth where they seek legitimacy. Thus, contrary to Feyerabend (1993), anything can simply not go - absolute relativism, like fundamentalism, is simply not a political option in the production of truth. Bad research will be rejected wherever it is presented. The issue is rather that good and valid research (depending on your criteria) may find a home in some journals and not in others. If all journals were equally relevant in promotion and tenure decisions, then this might have been the end of it — unfortunately it is not. We now want to return to the issue of academic publication. What does the politics of truth mean for research and publishing in academic journals?

It is important to realize - and tell our students - that academic publication is first and foremost a political rather than a pure epistemological issue. Obviously epistemological considerations are also important, but they can never be seen separately from the regime of truth within which the ultimate truth claims will be made. We claim that all research must be reasonable (as opposed to rational). And by this we mean it should be congruent with the regime of truth in which it locates itself. If you do positive research and want to publish in a positivist journal, you must adhere to that regime of truth. Likewise, the interpretivist must be congruent with that regime of truth. Ironically, even the post-modernist must appeal to a regime of truth for legitimacy. This implies that the researcher must make a significant effort to know the regime of truth to which she will eventually appeal. This is not easy. Foucault has taught us that power is only effective if it hides itself. Thus, the power relations that make up the regime of truth will be reluctant to spell out in detail what constituted legitimate claims as that would limit their room to manoeuver. It is, therefore, often necessary not so much to know the scope and aims of the journal as to know the particular dispositions of those who make the important decisions. Furthermore, the journals also seek legitimacy within the academic community. They themselves will, therefore, have to address themselves to that regime of truth. To the extent that the modern positivist regime of truth is still dominant, they will have to be seen to be scientific - at some level of analysis. Knowledge production is a complex set of power relations within and between regimes of truth that the experienced researcher must learn to negotiate. Publication in academic journals is an experience in disciplinary power, in Foucault's terminology. As we all know, we must be seen to address the reviewer's comments, even when we fundamentally disagree with them. Thus, a publication in MISQ, or any other journal, is not necessarily so much an indication of quality as it is an indication of compliance with the regime of truth that operates there. Indeed we often bemoan the quality of the work published in MISQ. Yet, the editors cannot fail to agree to publish work that obviously conforms to the disciplinary processes that make up the MISQ_-scope, method, reviewing, etc.

What we have said about MISQ is equally true for other journals such as Information Systems Research, Information and Organization, Journal of Management Information Systems, and so forth. We would argue that it would be very difficult if not impossible to publish a purely positivist paper in Information and Organization - even 
if the editor might wish to. We need to admit that since knowledge production-in the form ofpublications in this case - is a fundamentally social process, questions of epistemology cannot be separated from questions of politics. This is not bad-indeed it is the very condition of its ongoing possibility. However, it is dangerous, as Foucault has argued. It is our duty to continually disclose this politics of truth and to subject it to ongoing scrutiny. It is when power becomes hidden and systematically asymmetrical that it becomes bad. It is our belief that the systemic dominance of the MISQ in university rankings is bad for the field-our evident institutional silence on this politics oftruth is even worse. It is our moral duty to continually challenge any attempt to institutionalize rankings of journals that tend to favor certain regimes of truth and not othersespecially as this may have material consequences for those equally legitimate researchers on the outside.

\section{REFERENCES}

Baskerville, R., and Myers, M. "Information Systems as Reference Discipline," MIS Quarterly (25:1), 2002, pp. 1-14.

Benbasat, I., Goldstein, D. K., and Mead, M. "The Case Research Strategy in Studies of Information Systems," MIS Quarterly (11:3), September 1987, pp. 369-386.

Clegg, S. R. Frameworks of Power, London: Sage Publications Ltd., 1989.

Culnan,M. J. "Mapping the Intellectual Structure of MIS, 1980-1985: A Co-Citation Analysis," MIS Quarterly (11:3), 1987, pp. 341-349.

Culnan, M. J., and Swanson, E. B. "Research in Management Information Systems, 1980-1984: Points of Reference," MIS Quarterly (10:3), 1986, pp. 289-302.

Dickson, G. "The Apology of a Retiring Founding Editor," MIS Quarterly (6:4), 1982, pp. v-viii. Feyerabend, P. Against Method (3 ${ }^{\text {rd }}$ ed.), London: Verso, 1993.

Foucault, M. "Truth and Power," in Power/Knowledge: Selected Interviews and Other Writings 1972-1977, C. Gordon (Ed.), New York: Pantheon Books, 1977.

Foucault, M. "The Subject and Power," in Power: Essential Works of Foucault 1954-1984, Volume Three, James D. Faubion (Ed.), London: Penguin, 1994, pp. 325-348.

Giddens, A. The Constitution of Society: Outline of the Theory of Structuration, Oxford: Blackwell, 1984.

Habermas, J. Communication and the Evolution of Society, London: Heinemann Press, 1979.

Habermas, J. The Theory of Communicative Action, Volume 1, London: Heinemann Education, 1984.

Habermas, J. The Theory of Communicative Action, Volume 2, Cambridge: Polity, 1987.

Jacobsen, K. "Unreal Man," The Guardian, April 3, 2001, p. 12.

Kuhn, T. S. The Structure of Scientific Revolutions ( $2^{\text {nd }}$ ed.), Chicago: University of Chicago Press, 1970.

Latour, B. Science in Action: How to Follow Scientists and Engineers Through Society, Cambridge, MA: Harvard University Press, 1987.

Latour, B. We Have Never Been Modern, New York: Harvester, 1993.

Nietzsche, F. W. The Will to Power, translated by R. Hollingdale and Walter Kaufmann, London: Random House, 1967.

Orlikowski, W. J., and Barley, S. R. "Technology and Institutions: What Can Research on Information Technology and Research on Organizations Learn from Each Other," MIS Quarterly (25:2), 2001, pp. 145-165.

Schultze, U., and Leidner, D. "Studying Knowledge Management in Information Systems Research: Discourses and Theoretical Assumptions," MIS Quarterly (26:3), 2002, pp. 213242. 


\section{ABOUT THE AUTHORS}

Lucas Introna is a reader in Organisation, Technology, and Ethics in the Centre for the Study of Technology and Organisation at Lancaster University. His research interest is the social dimensions of information technology and its consequences for society. In particular he is concerned with the way information technology transforms and mediates social interaction with specific reference to the moral dimension. He was associate editor of Information Technology \& People (1996-2000) and is coeditor of Ethics and Information Technology. He is a founding member of the International Society for Ethics and Information Technology (INSEIT) and an active member ofIFIP WG 8.2, The Society for Philosophy in Contemporary World (SPCW), and a number of other academic and professional societies. His most recent work includes a book, Management, Information and Power published by Macmillan, and various academic papers in leading journals and conference proceedings on a variety of topics such as theories of information, privacy, surveillance, information technology and post-modern ethics, autopoiesis and social systems, and virtual organisations. He holds degrees in Management, Information Systems and Philosophy. Lucas can be reached at l.introna@lancaster.ac.uk

Louise Whittaker is a senior lecturer in Information Management at the Graduate School of Business Administration, University of the Witwatersrand in Johannesburg. Her research interests include the organizational effects of information technology, the evaluation of information systems, and information systems and organizational strategy. She is particularly interested in a phenomenological approach to understanding these issues. She completed her B.Com. and M.Com. degrees at the University of Witwatersrand and her Ph.D. at the University of Pretoria. Louise is a member of IFIP WG 8.2. Louise can be reached at whittaker.1@wbs.wits.ac.za 


\section{Appendix A}

\section{MISQ Editors from 1977 to 2004}

\begin{tabular}{|c|c|c|c|}
\hline Year & Vol. & Editor-in-Chief & Senior Editors \\
\hline 1977- 1982 & $1-6$ & Gary W. Dickson & \\
\hline 1973-1985 & $7-9$ & William R. King & \\
\hline 1986 & 10 & F. Warren McFarlan & \\
\hline $1987-1988$ & $11-12$ & F. Warren McFarlan & Izak Benbasat \\
\hline 1989 & 13 & James C. Emery & Izak Benbasat \\
\hline $1990-1991$ & $14-15$ & James C. Emery & Michael Ginsberg \\
\hline 1992 & 16 & Blake Ives & Michael Ginsberg \\
\hline 1993-1994 & $17-18$ & Blake Ives & Gerardine DeSanctis \\
\hline 1995 & 19 & Robert Zmud & $\begin{array}{l}\text { Izak Benbasat, Gerardine DeSanctis, Allen Lee, } \\
\text { Blake Ives }\end{array}$ \\
\hline 1996 & 20 & Robert Zmud & $\begin{array}{l}\text { Lynda Applegate, Izak Benbasat, Sirkka } \\
\text { Jarvenpaa, Allen Lee }\end{array}$ \\
\hline 1997 & 21 & Robert Zmud & $\begin{array}{l}\text { Lynda Applegate, Sirkka Jarvenpaa, Allen Lee, } \\
\text { Blake Ives, Kalle Lyytinen, Ron Weber }\end{array}$ \\
\hline 1998 & 22 & Robert Zmud & $\begin{array}{l}\text { Lynda Applegate, Blake Ives, Sirkka Jarvenpaa, } \\
\text { Kalle Lyytinen, Rick Watson, Ron Weber }\end{array}$ \\
\hline 1999 & 23 & Allen Lee & $\begin{array}{l}\text { Lynda Applegate, Cynthia Beath, Sirkka } \\
\text { Jarvenpaa, Kalle Lyytinen, Rick Watson, Daniel } \\
\text { Roby, Ron Weber, Robert Zmud }\end{array}$ \\
\hline 2000 & 24 & Allen Lee & $\begin{array}{l}\text { Cynthia Beath, Michael D. Myers, Daniel Roby, } \\
\text { Rick Watson, V. Sambamurthy, Jane Webster, } \\
\text { Kwok-Kee Wei, Ilze Zigurs, Robert Zmud }\end{array}$ \\
\hline 2001 & 25 & Allen Lee & $\begin{array}{l}\text { Cynthia Beath, Michael D. Myers, Daniel Roby, } \\
\text { Rick Watson, V. Sambamurthy, Jane Webster, } \\
\text { Kwok-Kee Wei, Ilze Zigurs, Robert Zmud }\end{array}$ \\
\hline 2002 & 26 & Ron Weber & $\begin{array}{l}\text { Ritu Agarwal, Allen Lee, Michael Myers, V } \\
\text { Sambamurthy, Peter Todd, Jane Webster, Kwok- } \\
\text { Kee Wei, Ilze Zigurs }\end{array}$ \\
\hline 2003 & 27 & Ron Weber & $\begin{array}{l}\text { Ritu Agarwal, Deborah Compeau, Allen Lee, } \\
\text { Michael Myers, Rajiv Sabherwal, V } \\
\text { Sambamurthy, Carol Saunders, V. Storey, Peter } \\
\text { Todd, Jane Webster, Kwok-Kee Wei }\end{array}$ \\
\hline 2004 & 28 & Ron Weber & $\begin{array}{l}\text { Ritu Agarwal, Deborah Compeau, Allen Lee, } \\
\text { Lars Mathiassen, Michael Myers, Rajiv } \\
\text { Sabherwal, Carol Saunders, Veda Storey, Peter } \\
\text { Todd, Bernard Tan, Dov Te'eni }\end{array}$ \\
\hline
\end{tabular}

